\title{
A comparative study of different segments in the South African lending industry
}

\author{
J. Volschenk* and N. Biekpe \\ Africa Centre for Investment Analysis \\ University of Stellenbosch Business School \\ PO Box 610, Bellville 7535, Republic of South Africa \\ jakov@acia.sun.ac.za
}

Received January 2003

\begin{abstract}
The efficiency and availability of financial services for the poor is a global problem, and has only recently started to attract attention in South Africa. This paper aims to examine the South African microfinance industry by comparing sector-related differences in the ranking of specific problems. Tests for the significance of differences (in the location of specific populations) indicate significant differences in perceptions regarding certain intra-industry segments within the microcredit industry. The recent arguments in favour of a single regulator imply that the financial industry as a whole (commercial and microlending sectors) is homogeneous in its priorities. However, the results in this paper suggest that there is no significant agreement between the priorities of the commercial and microlending industries.
\end{abstract}

*To whom all correspondence should be addressed.

\section{Introduction}

The South African microcredit industry is relatively young and little is known about the real issues facing the industry due to limited research done on the sector. Although the commercial lending (that is banking) sector has been thoroughly researched, the micro-industry has not enjoyed the same level of investigation. This is mainly because of a lack of adequate data.

Identifying key issues facing the micro-sector is always the first step towards any meaningful research and would enable regulators to focus on identifying and designing sustainable strategies.

This paper presents primary data gathered from the South African microfinance sector in 2002. It investigates institutions that serve different market-segments, firstly in the wide lending industry and secondly within the microfinance industry. The investigation is done in terms of the priorities these institutions assign to specific problems experienced in the wider South African lending industry.

The first area of investigation is the market-segmentation within the micro-industry (intra-industry comparison). Secondly, the paper compares the priorities of the microlending industry with that in the commercial banking sector (inter-industry comparison). The latter is done with the sole purpose of discussing the proposed single regulator for all the levels in the South African financial sector.

\section{Market segmentation within the microfinance industry}

Managers of microfinance institutions (MFIs) report to their shareholders, financiers and sponsors and would therefore prefer to operate in the market with the highest return and the lowest risk features. In order to accomplish this, managers have a number of choices in terms of which markets to target (e.g. gender or income bias) and the kind of products they are willing to offer (e.g. loan-insurance, short- or long term loans, etc.). A number of authors (e.g. Chao-Beroff, 1999; Lok, 2000a \& 2000b; Quiñones, 2000; Charitonenko \& Rhaman, 2002) deal extensively with market-segmentation. These authors differentiate between urban and rural clients, group and individual loans and examine gender characteristics. Within the microfinance industry, each of these market-segments possesses distinct risk-return profiles.

According to Chao-Beroff (1999: 22) rural areas offer considerably less return than urban areas. His research shows that low population density could result in a lender spending up to $20 \%$ of his income on reaching his clients. The incomes of MFI-clients are generally somewhat precarious and irregular, while long distances often separate the MFI from its clients. Significant investments are necessary to remove these constraints. These recurring costs make operating in rural areas more expensive than working in cities or big towns.

Urban moneylenders have quite different problems compared to their rural counterparts and are more prone to experience problems related to the large number of 
competitors and clients. The large number of clients and high turnover of new borrowers mean that loanadministrators seldom know the clients well. Consequently fraud becomes more of an issue and locating a person becomes almost impossible.

The impact of fraud is diminished when groups can be used to protect the lender, i.e. the MFI. Collateral-free lending becomes possible (Quiñones, 2000: 13; Kiweu, 2002: 27) through group-pressure and group-guarantees. Often only one or two members of a group can make a loan at a time, increasing the pressure to repay the loan, while the group as a whole can be expected to take responsibility for bad debts in the group. This implies that costs can be reduced by shifting it to the group. Furthermore, group schemes bind clients to the groups and consequently to the MFI.

However, even though group-based schemes have excellent repayment rates during good years, repayment rates are worse in crisis years (Quiñones, 2000:13). It also means that clients have to be trained to understand the schemes, at higher transaction cost to the MFI. Lastly, given that the lender-borrower relationship is virtually non-existent, it is not surprising that many clients prefer using individual schemes. Charitonenko and Rhaman (2002: 35) found a trend in Bangladeshi MFIs towards individual loans, but loan sizes still rely on historical repayment, making it more risky than Grameen ${ }^{1)}$-style loans.

It has been widely documented that women are better clients than men (Lok, 2000a: i; International Labour Organisation, 1996). Women are generally closer to their homes, are easier to organise and are easier to find for frequent visits by credit officers (Charitonenko \& Rhaman, 2002: 34). Furthermore, women show stronger bonds to a group-scheme and are committed to preserve access to resources for their families. One would therefore expect to find a large proportion of MFIs lending to women, or even favouring female clients. This was indeed found to be the case in Asia (Lok, 2000a: 11). In Bangladesh, women account for as much as $90 \%$ of MFI clientele (Charitonenko \& Rhaman, 2002: 34). In Latin America, Lok (2000b: 9) found that the balance is more equal. She found that most financing institutions have a female membership of between 26 and 75 percent of all its clients. Generally, Lok (2000a, 2000b) found that institutions with a larger number of small loans had a higher percentage of women as clients.

Other segmentation criteria include criteria based on income and product-options, such as loan-insurance (Brown \& McCord, 2000; Brown \& Churchill, 2000). Although discussions surrounding these issues are common, none of the authors identify any risk-return characteristics. The questions that remain are whether it is more risky to lend to poorer clients, and whether value-added products such as loan-insurance prevent defaults or protect MFIs against losses. These questions will be addressed later in this paper.

\footnotetext{
1) The Grameen Bank in Bangladesh is considered one of the best examples of a bank operating successfully in the microfinance field using group-based loans.
}

\section{Regulation of the microfinance industry}

The South African lending sector is a four-tier system, similar to that found in other developing countries, e.g. in East Africa (Masinde, 2001: 1). The South African Reserve Bank (SARB) operates as the banker of banks at the top level. The second level contains all commercial banks and the third consists of the microfinance institutions. As commercial banks try to enter the microfinance industry, the distinction between level two and level three becomes less defined. In South Africa it is more common to find institutions in level 2 (commercial institutions) that move down into level 3 (micro-industry) than vice versa. The main reason for the asymmetrical movement is the extensive capital-requirements needed to be classified as a bank. The fourth (bottom) level consists of informal finance schemes such as stokvels and other community based organisations.

The third level institutions, i.e. MFIs, benefit from an exemption from the Usury Act. Microcredit institutions are not expected to keep the interest rates they charge below the interest rate ceiling that the commercial lenders must adhere to. This exemption was made as a result of structural change in the economy and did not originate from the South African Reserve Bank.

Despite its role as regulator of the commercial banking sector, the Reserve Bank currently fulfils a limited role in the effort to bank the unbanked. The Microfinance Regulatory Council (MFRC) acts as regulator of the microfinance industry. This is different from a number of countries, e.g. the Nordic countries, Canada and more recently the United Kingdom and Australia (Financial Mail, 2002a: 26-27), where one regulator oversees all types of financial institutions. The before-mentioned countries are all considered developed countries and have relatively homogeneous financial sectors. The Minister of Finance argues that South Africa has a well-developed financial system, and should therefore rather move towards unification of the regulators (Financial Mail, 2002a: 26-27). Based on his experience in East Africa, Ferrand (2001: 32) disagrees with this view. He suggests a tiered approach where the lower levels (NGOs/MFIs) are not regulated by the same institutions as the higher level institutions e.g. commercial banks.

Although the South African banking sector is globally recognised as well developed, it is important to realise that the country is still regarded as developing in socio-economic terms. It is in many respects closer to a country like Bangladesh than it is to developed countries. Because of this link, the example of Bangladesh becomes relevant to South Africa. Charitonenko and Rhaman (2002: 42) suggested that Bangladesh should adopt a tiered approach to regulation of MFIs, with at least a distinct unit inside the central bank or a third party with regulatory powers. They base their suggestion on the limited expertise of the Bangladesh Bank in the field of microfinance.

In South Africa, a number of commercial banks have tried to enter the microfinance sector but failed to do so [the collapse of Saambou and Unifer as well as the run on BOE Bank being the best known cases (Financial Mail, 2002b: 
14)]. When taken into account that the Reserve Bank acted as regulator in these cases, it is safe to postulate that it, like the Bangladesh Bank, lacks the capacity to regulate MFIs. Charitonenko and Rhaman's (2002: 42) argument against a single regulator is therefore equally valid in South Africa.

Whether the Reserve Bank should regulate the microfinance industry relies on whether MFIs face the same issues found in the commercial lending industry. The government created the formal microcredit industry and acknowledged its uniqueness in doing so, i.e. it is a separate industry with unique priorities. However, the recent movement towards a single regulator (Theobald, 2002: 24-25) would imply that the financial industry as a whole (specifically the banking and microfinance sectors) is homogeneous in the issues it faces. One would be able to test this assumption (homogeneous industry) if the priorities in dealing with these issues were known for both the commercial and microlending sectors. Unfortunately only the priorities of the commercial lending sector are known. In a report by PriceWaterhouseCoopers (Metcalfe, 2002) a list of the most pressing strategic issues in the commercial banking sector was presented. The four biggest issues identified were profit performance, service quality, client focus and improving revenue growth.
One of the major objectives of this paper was therefore to determine the priorities in the microfinance sector. How the priorities of the two sectors compared will be discussed later in this paper.

\section{Methodology}

There is limited data available on the South African microfinance industry. In this paper, primary data is presented concerning the microfinance sector and its priorities. The population under study was South African microcredit institutions. A sample of 800 MFIs was randomly selected from the Micro Finance Regulatory Council (MFRC) database and questionnaires were designed and faxed to them. Fifty-three MFIs responded to the survey, implying a response rate of $6.6 \%$.

The issues listed in the survey were chosen from issues mentioned and discussed in depth by various authors (Metcalfe, 2002: 13; Masinde, 2001: 1; Lok, 2000a and 2000b; Ahmed, 2002: 52; Rutherford, 2000a: 114; Naidoo, 2002: 6). Using the categories suggested by Masinde (2001: $1)$, the issues were split into the four levels considered as encompassing all issues, i.e. strategic, operational, marketing as well as capitalisation issues (see Table 1).

Table 1: Problems/issues/challenges included in survey

\begin{tabular}{|c|c|}
\hline Collective group & Problems/Issues \\
\hline Strategic issues & $\begin{array}{ll}\text { - } & \text { Increased competition }^{\mathrm{a}} \\
\text { - } & \text { Education level of staff } \\
\text { - } & \text { Ownership structure unclear/donor intervention } \\
\text { - } & \text { Legislation and regulatory framework } \\
\text { - } & \text { Skills development of staff } \\
\end{array}$ \\
\hline Operational issues & $\begin{array}{ll}\text { - } & \text { Quality of loan books (credit risk, delinquency and default) } \\
\text { - } & \text { Profit performance } \\
\text { - } & \text { High costs }{ }^{\mathrm{b}, \mathrm{c}} \\
\text { - } & \text { Attracting low-income clients (poor client response) } \\
\text { - } & \text { Retaining existing clients } \\
\text { - } & \text { Small and irregular cash flows from clients } \\
\text { - } & \text { Poor selection practices } \\
\text { - } & \text { Appropriate staff incentive schemes } \\
\text { - } & \text { Low population density } \\
\text { - } & \text { Fraud } \\
\text { - } & \text { Service Quality } \\
\end{array}$ \\
\hline Marketing issues & $\begin{array}{ll}\text { - } & \text { Education level of clients }{ }^{\mathrm{f}} \\
\text { - } & \text { Client focus }{ }^{\mathrm{a}, \mathrm{b}} \\
\text { - } & \text { Lack of information about clients }{ }^{\mathrm{d}}\end{array}$ \\
\hline Capitalisation issues & - $\quad$ Lack of capital to lend to clients (donor funding) ${ }^{b, d}$ \\
\hline
\end{tabular}

Sources: ${ }^{\mathrm{a}}$ Metcalfe, 2002: 13; ${ }^{\mathrm{b}}$ Masinde, 2001: 1 ; ${ }^{\mathrm{c}} \mathrm{Lok}, 2000 \mathrm{a}$ and 2000b; ${ }^{\mathrm{d}}$ Ahmed, 2002: 52; ${ }^{\mathrm{e}}$ Rutherford, 2000a: $114 ;{ }^{\mathrm{f}} \mathrm{Naidoo}, 2002: 6$

\section{Methodology in ranking the issues}

MFI managers were asked to rank the issues in Table 1 according to the extent to which they pose a problem in the particular MFI. The scale used ranged from 1 (small problem) to 4 (major problem).

The data (which is non-parametric) surrounding each issue was used to calculate an average for the particular problem.
Although these averages could be considered as rather crude statistics, they do offer the ability to rank the issues by these parametric averages.

\section{Methodology in finding market-related trends}

In order to compare different (intra-industry) marketsegments the data sets were filtered by income, gender, product-data, province, degree of urbanisation and by 
whether loans were granted to individuals or groups. The Kruskal-Wallis test was used to test for significant differences in the location between the different filtered subsamples. [Location could be described as the equivalent of an average, but for ranked (non-parametric) data. The Kruskal-Wallis test tells us when a data-set is consistently ranked significantly higher or lower than another data-set]. In the case of the Kruskal-Wallis test for a difference in the location of two or more groups of MFIs, the null and alternative hypotheses were:

$\mathrm{H}_{0}$ : The locations of the two or more populations are the same. (The two market-segments rate a problem from Table 1 similarly.)

$\mathrm{H}_{\mathrm{A}}$ : At least two populations differ in location.

\section{Methodology in comparing the microcredit and commercial credit sectors}

The proposed single regulator for the financial sector assumes that the different levels of service-provision (commercial and micro) are homogeneous in their priorities. To test this assumption the priorities found in the microfinance-survey had to be compared to the priorities as reported by Metcalfe (2002: 13). If it was found that the priorities correspond to a large degree, then one could argue that a single regulator might be able to increase efficiency through economies of scales and synergies. However, if the correspondence was low, there will be very little to gain by amalgamating the regulators into one.

To test for correlation between the two levels, the Spearman rank correlation coefficient was used. The null and alternative hypotheses were specified as:

$\mathrm{H}_{0}: \rho_{0}=0$ (There is no linear relationship between the two variables.)

$\mathrm{H}_{\mathrm{A}}: \rho_{0} \neq 0$.

With $\alpha=0.05$ and $n=11$ (eleven of the issues in the microfinance survey overlaps with similar issues in the report by Metcalfe), the rejection region for the two-tail test was $\left|\mathrm{r}_{\mathrm{s}}\right|>1.046$.

\section{Findings and Discussion}

\section{Priorities in the South African Microcredit Industry}

Respondents in the survey were asked to rank each of the 20 issues in the questionnaire by the extent to which it poses a problem to the particular MFI. The ranked list shown in Figure 1 (more complete data available in Appendix 1) would be of interest to regulators and MFIs alike. It offers the opportunity to focus on solving the problems that may benefit the industry most. It is clear that the high cost structure in the microfinance sector is perceived to be the most pressing issue, followed closely by bad debts and precariousness of cashflows from microfinance clients.

No investigation was made to determine the factors that contribute towards the high cost structure. It is a complex issue with numerous drivers, some of which are shown in Figure 1 .
Three major cost-drivers not mentioned in Figure 1 were identified using an open-ended question. The first is the lack of an efficient collection system to replace the old and illegal 'card and pin ${ }^{2)}$ '-method. In the absence of an efficient collection system, both the cost and bad debts increase. Of the top five issues in Figure 1, at least four are directly related to the absence of a good collection method.

The MFRC lacks the power to act against illegal lenders while some registered MFIs feel over-regulated. Registered lenders complain about the high fees associated with MFRC-affiliation, without any obvious advantage gained from it. Unregistered lenders don't pay any of these fees while exploiting clients. Yet the MFRC fails to demonstrate the capacity to act against these illegal lenders.

Furthermore, reporting to the MFRC increases administration costs as well as the opportunity cost of not being able to carry out other productive tasks, e.g. visiting clients, training of staff, etc. Registered MFIs feel these factors give unregistered lenders an unfair competitive advantage.

\section{Trends found in the perceptions of the South African MFI industry}

By creating sub-samples within the bigger sample of MFIs, it was possible to study differences in location of certain intra-industry populations or market-segments. Table 2 indicates differences in location at $10 \%(\checkmark)$ and $5 \%$ significance $(\checkmark \checkmark)$ levels. Appendices 2 to 6 report the statistical analysis surrounding the significance of differences in the location of market-segments.

\section{Groups vs. individuals}

It is generally believed that lending to groups rather than individuals should offer protection from several risks mentioned in the survey, e.g. high costs, the quality of loan books, low population density, etc (Kiweu, 2002; Lok, 2000a \& 2000b; Charitonenko \& Rhaman, 2002: 34). The results from the survey indicate that individual loans are perceived to be significantly more expensive than using group-schemes. Yet on other attributes the ratings show only moderate differences in location.

No significant difference in location was found in the quality of loan books, which was surprising as groupschemes are often used to protect the lender against portfolio-risk. It could therefore be argued that groupschemes are driven by the need for low-cost schemes rather than the need to reduce the risk-profile of the loan-books.

\footnotetext{
2) The card and pin method refers to the practice of keeping a client's bank-card as collateral and withdrawing the amount owed (by using the client's secret pin) before returning the card. It is currently an illegal practice, but still widely used in the absence of a better solution.
} 


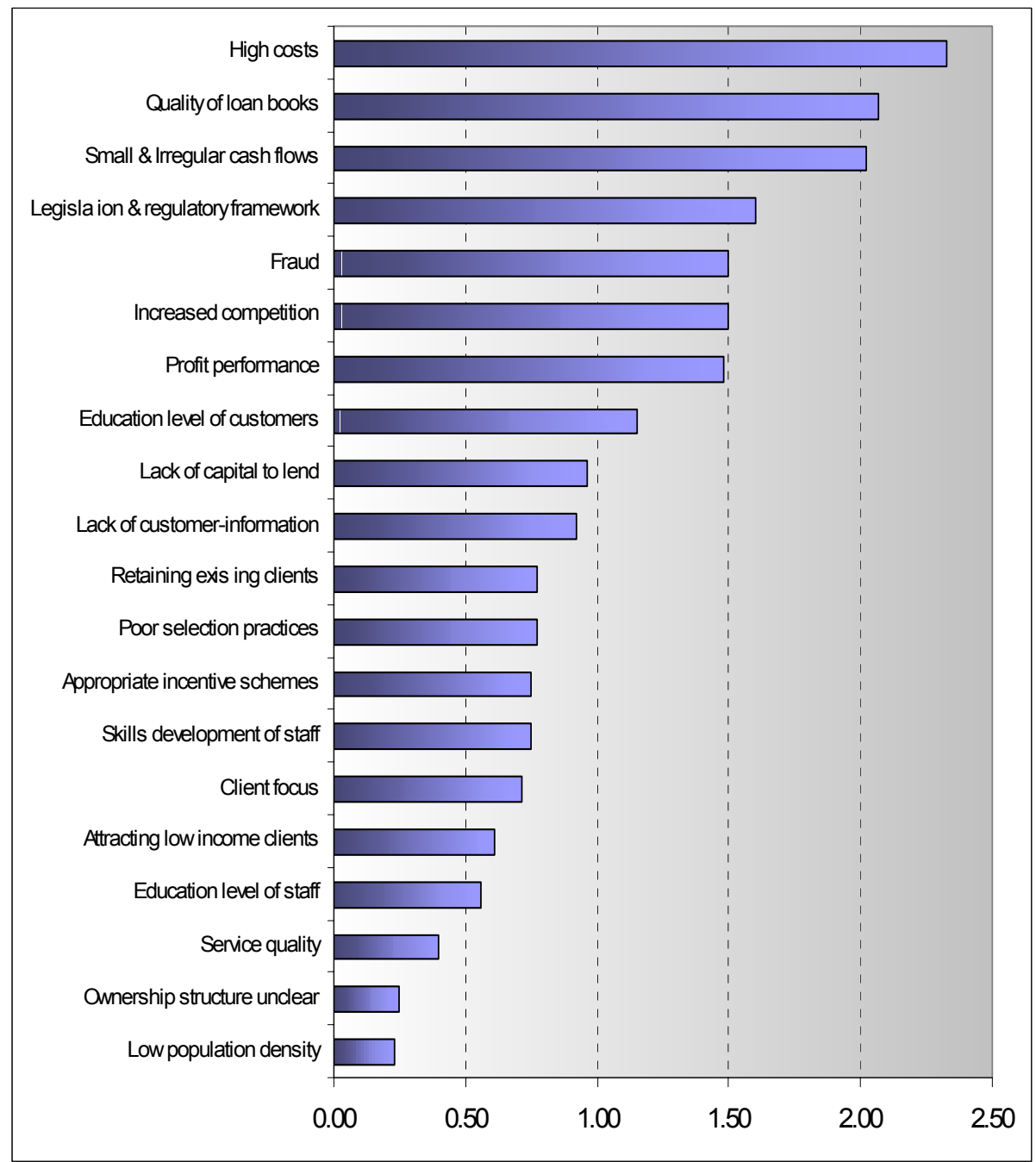

Figure 1: Average ratings as obtained in microfinance survey

Although the literature-review indicated that borrowers ought to prefer individual schemes to group schemes, no such conclusion could be drawn from the survey. MFIs lending to groups do not perceive client satisfaction or service quality to clients to be more of an issue than MFIs lending to individuals ${ }^{3)}$. On the contrary, it seems as if client satisfaction might even be less of an issue for MFIs using group-based schemes. Appendix 2 documents a complete summary of the analysis.

\section{Urban vs. rural}

By far the highest number of significant differences in location was found between MFIs operating in urban areas and those operating in both urban and rural areas (Appendix 3 ). Five attributes were significant at the $10 \%$ level. These attributes were fraud, high costs, small and irregular cash flows, quality of loan books and increased competition. All five attributes were rated consistently higher in rural areas, reflecting a more serious nature. These issues explain, to a large extent, why MFIs prefer working in urban areas rather than in rural areas.

\footnotetext{
${ }^{3)}$ Keep in mind that the survey recorded the perception from the supply side and not from clients themselves.
}

\section{Provincial trends}

In terms of differences in the perceptions in different provinces, the only issue that did show any significant difference in perception was 'Legislation and regulatory framework' (see Appendix 4). Of the three provinces analysed (Gauteng, Western Cape and Eastern Cape), the Eastern Cape rated this issue the highest. No explanation for this could be found, as these three provinces are all regulated by the MFRC.

\section{Product-specific trends}

Providing loans cum insurance is not perceived to lower the risk of default. Neither does it reduce costs or increase profits. The absence of any significant differences ${ }^{4)}$ is rather surprising, as it seems that offering insurance does not influence the perceptions surrounding costs, profits or fraud.

\footnotetext{
4) A false positive test was obtained in the case of 'increased competition'. The reported difference in location (Appendix 5) can be explained by the fact that the product-specific samples were further split into urbanisation-specific groups. As reported earlier, a significant difference exists between the two urbanisation-specific sub-samples, causing the H-value for 'increased competition' to show a false positive test.
} 
Based on the perceptions in the industry, there would be no motivation from the side of an MFI to offer loan-insurance.

\section{Income-related trends}

In order to research the influence of income on risk-return properties, some noise had to be removed by dividing the sample of MFIs into a 'rural and urban' and 'urban' before breaking it into income-specific markets. This two-fold division effectively split the total sample into four segments as shown in Figure 2 (see Appendix 6).

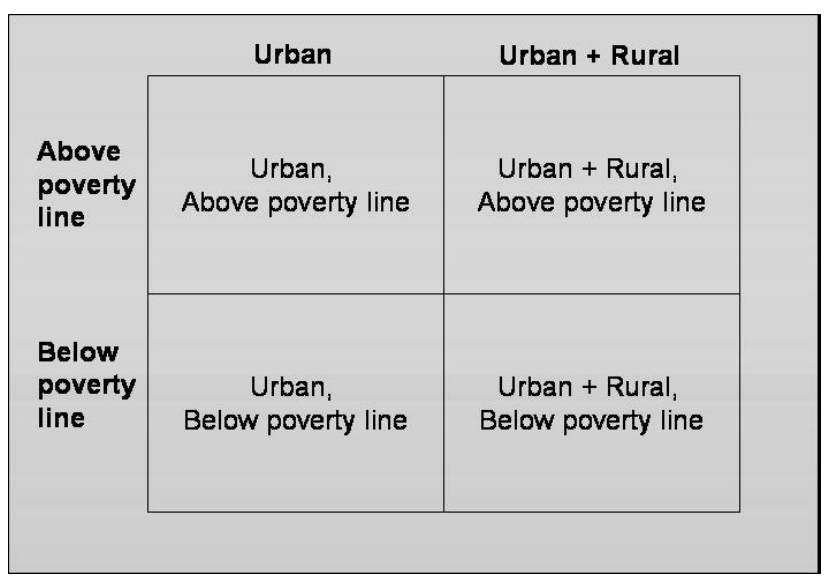

A Figure 2: Urbanisation and income segmentation

16 percent leves wnen a comparison is made oetween income-specific segments. These attributes are shown in Table 2. In all of the cases the difference in location is in favour of the higher income group, except in terms of information about clients.

The analysis indicates that the low-income group itself is partly responsible for the unwillingness of the microcredit industry to lend to the very poor. Lower income groups are perceived simultaneously as more risky and less profitable. No prudent investor would consider lending to such a segment unless the mandate is solely aimed at poverty alleviation.

\section{Male vs. female clients}

Very few MFIs indicated making loans based on gender, deeming it impossible to make useful deductions regarding issue-related differences from the data. However, in itself it is somewhat surprising as a number of best practice models (Lok, 2000a \& 2000b; International Labour Organisation, 1996; Charitonenko \& Rhaman, 2002) refer to women as lower risk clients. In this regard, the make-up of the South African microfinance industry differs completely from other parts of the word, particularly the Asian countries, e.g. Bangladesh.

Table 2: Issues that showed difference in location of populations $(\alpha<0.1)$

\begin{tabular}{|c|c|c|c|c|c|c|c|}
\hline \multirow[t]{2}{*}{ Rank } & \multirow[t]{2}{*}{ Issue in survey } & \multirow{2}{*}{$\begin{array}{c}\text { Group/ } \\
\text { individual } \\
\text { difference }\end{array}$} & \multirow[t]{2}{*}{$\begin{array}{l}\text { Urban/ rural } \\
\text { difference }\end{array}$} & \multirow[t]{2}{*}{$\begin{array}{l}\text { Provincial } \\
\text { difference }\end{array}$} & \multirow[t]{2}{*}{$\begin{array}{l}\text { Product } \\
\text { difference }\end{array}$} & \multicolumn{2}{|c|}{$\begin{array}{c}\text { Income } \\
\text { difference }\end{array}$} \\
\hline & & & & & & Urban & Both \\
\hline 1 & High costs & $\checkmark$ & $\checkmark \checkmark$ & $x$ & $x$ & $x$ & $x$ \\
\hline 2 & Quality of loan books & $x$ & $\checkmark$ & $x$ & $x$ & $x$ & $\sqrt{ } \sqrt{ }$ \\
\hline 3 & $\begin{array}{l}\text { Small and irregular cash flows } \\
\text { from clients }\end{array}$ & $x$ & $\checkmark \checkmark$ & $x$ & $x$ & $x$ & $\checkmark$ \\
\hline 4 & $\begin{array}{l}\text { Legislation and regulatory } \\
\text { framework }\end{array}$ & $x$ & $x$ & $\checkmark$ & $x$ & $x$ & $x$ \\
\hline 5 & Fraud & $x$ & $\sqrt{ }$ & $x$ & $x$ & $\checkmark$ & $x$ \\
\hline 6 & Increased competition & $x$ & $\checkmark$ & $x$ & $x$ & $x$ & $x$ \\
\hline 7 & Profit performance & $x$ & $x$ & $x$ & $x$ & $\checkmark \checkmark$ & $x$ \\
\hline 8 & Education level of clients & $x$ & $x$ & $x$ & $x$ & $x$ & $x$ \\
\hline 9 & Lack of capital to lend to clients & $x$ & $x$ & $x$ & $x$ & $x$ & $x$ \\
\hline 10 & Lack of information about clients & $x$ & $x$ & $x$ & $x$ & $x$ & $\checkmark \checkmark$ \\
\hline 11 & Retaining existing clients & $x$ & $x$ & $x$ & $x$ & $x$ & $x$ \\
\hline 12 & Poor selection practices & $x$ & $x$ & $x$ & $x$ & $x$ & $x$ \\
\hline 13 & $\begin{array}{l}\text { Appropriate staff incentive } \\
\text { schemes }\end{array}$ & $x$ & $x$ & $x$ & $x$ & $x$ & $x$ \\
\hline 14 & Skills development of staff & $x$ & $x$ & $x$ & $x$ & $x$ & $x$ \\
\hline 15 & Client focus & $x$ & $x$ & $x$ & $x$ & $x$ & $x$ \\
\hline 16 & Attracting low income clients & $x$ & $x$ & $x$ & $x$ & $x$ & $x$ \\
\hline 17 & Education level of staff & $x$ & $x$ & $x$ & $x$ & $x$ & $x$ \\
\hline 18 & Service quality to customers & $x$ & $x$ & $x$ & $x$ & $x$ & $x$ \\
\hline 19 & $\begin{array}{l}\text { Ownership structure unclear/ } \\
\text { donor intervention }\end{array}$ & $x$ & $x$ & $x$ & $x$ & $x$ & $x$ \\
\hline 20 & Low population density & $x$ & $x$ & $x$ & $x$ & $\checkmark^{\mathbf{a}}$ & $x$ \\
\hline
\end{tabular}

${ }^{\text {a }}$ Low population density shows a difference in location with a confidence level of $89,7 \%$ 
Comparison of microcredit vs. commercial credit industries

In order to establish if the South African financial sector is indeed homogeneous, the priorities found in the microfinance survey was compared to the priorities in the commercial credit industry as reported by Metcalfe (2002). Table 3 shows an inter-industry comparison of the two survey rankings.

The results in Table 4 indicate that the null hypothesis of no linear relationship between the two variables should be accepted. Even though both industries agree that 'high costs' is the most pressing problem, there is almost no agreement on the remaining issues. It therefore becomes difficult to justify a single regulator if the decision would be based on a homogeneous industry argument. A 'mega-regulator' (Theobald, 2002: 24-25) would not be able to manage two distinct sectors as a uniform entity.

\section{Conclusion}

In terms of the issues in the microcredit industry, a clear list of priorities can be listed from the perceptions in the industry. However, it seems that problems such as efficient collection methods and the fee structure associated with MFRC registration should be added to the list of most pressing problems in the industry. The list of ranked issues should serve as guideline to legislatory and regulatory bodies in creating solutions that show maximum impact. It seems that the cost structure in the industry is a particular pressing issue, illustrated by the fact that $80 \%$ (Appendix 1) of respondents saw it as a problem that needs solving.

Furthermore, it was shown that there are a number of significant differences in the perceptions of MFIs operating in different segments. Factors like income, the level of urbanisation and the use of group-schemes can have a significant impact on the efficiency of an organisation.

The absence of trends in itself can be illuminating. MFIs do not perceive that group schemes reduce fraud or the impact of poor selection practices, even though this has been repeatedly cited in the literature (Quiñones, 2000: 13; Kiweu, 2002: 27).

The market segment in the micro-industry with the best riskreturn profile is the segment excluding rural areas and which contains groups of higher income clients. To take advantage of the information presented, MFIs operating with the mandate to generate returns for their investors should target this specific segment. Whether to offer loan-insurance or other loan-related products makes no apparent difference in terms of risk-return properties.

\section{Table 3: Comparison between the PriceWaterhouseCoopers and microfinance surveys}

\begin{tabular}{lc|c|l}
\cline { 2 - 4 } Description in microfinance questionnaire & $\begin{array}{c}\text { Position in } \\
\text { Microfinance } \\
\text { Survey }\end{array}$ & $\begin{array}{c}\text { Position in PWC } \\
\text { Survey (2002)* }\end{array}$ & Description in PWC questionnaire* \\
\hline $\begin{array}{l}\text { Quality of loan books (credit risk, delinquency } \\
\text { and default) }\end{array}$ & 2 & 8 & Quality of loan books (credit Risk) \\
\hline Legislation and regulatory framework & 4 & 6 & Addressing new compliance and regulations \\
\hline Increased competition & 6 & 10 & Increased competition \\
\hline Profit performance & $7^{\mathrm{a}}$ & 1 & Profit performance \\
\hline Retaining existing clients & 11 & 4 & Retaining existing clients \\
\hline Appropriate staff incentive schemes & 13 & 9 & Appropriate staff incentive schemes \\
\hline Skills development of staff & 14 & 12 & Recruiting/Training of front office staff \\
\hline Client focus (delivering what clients want) & 15 & $2^{\mathrm{b}}$ & Client focus \\
\hline $\begin{array}{l}\text { Attracting low-income clients (poor client } \\
\text { response) }\end{array}$ & 16 & 9 & Building a client base \\
\hline Education level of staff & 17 & 12 & Recruiting/Training of front office staff \\
\hline Service quality to customers & 18 & $2^{\mathrm{b}}$ & Service quality \\
\hline
\end{tabular}

*Source: Metcalfe, 2002: 13

${ }^{\text {a }}$ By assuming that profit performance and high costs address the same issue, the end result does not change, yielding a correlation coefficient of $r_{s}=-0.1652$

${ }^{\mathrm{b}}$ Client focus and service quality in the PWC survey was considered to be in a joint position.

Table 4: Result to Spearman rank correlation test

\begin{tabular}{l|r}
\hline Correlation coefficient & 0,087 \\
\hline Test statistic & $\mathrm{Z}=0,275$ \\
\hline Two-tail P-value & 0,833 \\
\hline
\end{tabular}

The issues experienced by the microfinance sector are not experienced at exactly the same levels by the commercial credit sector. It is clear from this piece that the South
African government should be cautious about unifying the different financial boards into one if that involves managing them under the assumption that the whole sector is homogeneous. Although a rather crude comparison, the low agreement between the micro and commercial credit sectors indicate that the two industries are unique in their priorities. Therefore the South African government should strive to regulate the microcredit and commercial credit industries as separate and unique industries. 


\section{Acknowledgements}

The authors would like to thank Therese Fish and Adri Saayman for their useful comments and input.

\section{References}

Ahmed, R. 2002. 'Microfinance regulations in South Africa: Status and challenges'. Paper presented at One-day seminar on microfinance best practices: Essential growth-path in Africa. Africa Centre for Investment Analysis, Bellville.

Brown, W. \& Churchill, C. 2000. Insurance provision in low-income communities - Part II. Microenterprise Best Practices: Arlington.

Brown, W. \& McCord M. 2000. Summary of discussions: USAID MBP virtual conference on microinsurance. Microenterprise Best Practices: Arlington.

Chao-Beroff, R. 1999. 'The constraints and challenges associated with developing sustainable microfinance systems in disadvantaged rural areas in Africa', United Nations Capital Development Fund (UNCDF). [online] URL:http://www.undp.org/sum/sum_reports/ftp_downloads/ chao_beroff_study.pdf

Charitonenko, S. \& Rahman, S. 2002. Commercialization of microfinance. Asian Development Bank: Manilla. Phillipines

Del Conte, A. 2000. 'Roundtable on micro-insurance services in the informal economy: The role of microfinance institutions'. The Ford Foundation: New York. [online] URL:www.swwb.org/English/pdf/Roundtable.pdf

Ferrand, D. 2001. 'Challenges for the microfinance sector in East and Southern Africa'. From keynotes of the MicroSave-Africa workshop held in Nairobi on the $13^{\text {th }}$ September 2001.

Financial Mail. 2002a. Merging the hydra's heads: An interview with Trevor Manuel. 14 June:26-27.

Financial Mail. 2002b. Nice and easy is the way to go on a single regulator. June 14:14.

International Labour Organisation, 1996. Action to assist rural women: Gender analysis study. Geneva: ILO
Kiweu, M. 2002. 'Risk management best practices in microfinance: What works'. Paper presented at the One-day seminar on Microfinance Best Practices: Essential GrowthPath in Africa. Africa Centre for Investment Analysis: Bellville.

Lok, C. 2000a. Global directory of banking innovation in microfinance - Sections on Asia. New York: Women's World Banking.

Lok, C. 2000b. Global directory of banking innovation in microfinance - Sections on Latin America. New York: Women's World Banking.

Masinde, C. 2001. Challenges facing the microfinance industry in India. From keynotes of the MicroSave-Africa workshop held in Nairobi on the $13^{\text {th }}$ September 2001.

Metcalfe, B. 2002. Strategic and emerging issues in South African banking: 2002 Edition. PriceWaterHouseCoopers, South Africa. [online] URL:http:// www.pwcglobal.com/ZA/ENG/ABOUT/PRESS-RM/ media-office/leadership/pwc

StrategicAndEmergingIssuesInSABanking.pdf

Naidoo, S. 2002. 'Microlending is stronger after the crisis'. Business Report: Special Survey on Microfinance. July 16, 2002.

Quiñones, B. 2000. 'Microfinance as an instrument of poverty alleviation: An overview'. Rajendrapur, Bangladesh: INASIA. [online]URL:http://

dhaka.inasia.lk/ressources/documents/rtf/BQ rtf

Quistgaard, K. 1998. 'Microlending in Bangladesh'. [online] URL:http://www.wired.com

Rutherford, S. 2000a. The poor and their money. Delhi: Oxford University Press

Theobald, S. 2002. 'Manuel's mission'. Financial Mail, 14 June:24-25. 
Appendix 1: Summary of scores

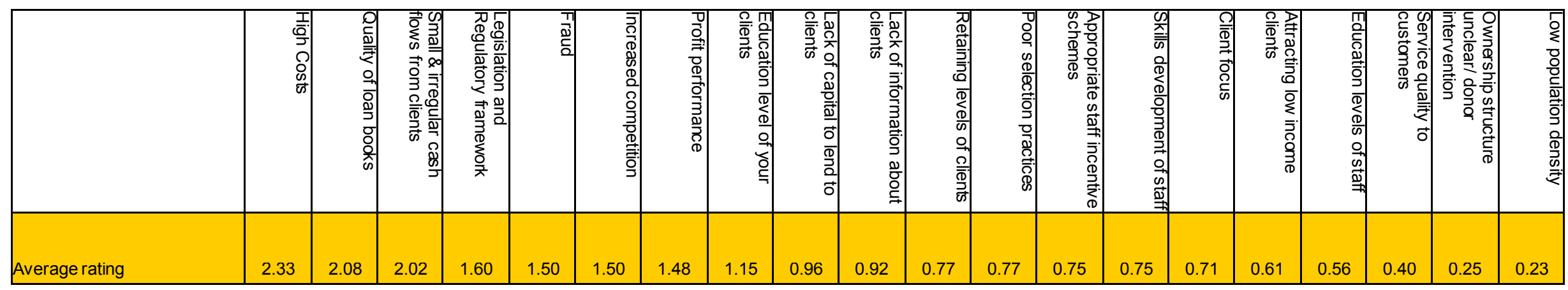

\begin{tabular}{|l|l|l|l|l|l|l|l|l|l|l|l|l|l|l|l|l|l|l|l|l|}
\hline Total Yes (\% of responses) & $79 \%$ & $75 \%$ & $77 \%$ & $56 \%$ & $67 \%$ & $62 \%$ & $58 \%$ & $50 \%$ & $31 \%$ & $46 \%$ & $40 \%$ & $37 \%$ & $44 \%$ & $31 \%$ & $31 \%$ & $23 \%$ & $25 \%$ & $17 \%$ & $12 \%$ & $12 \%$ \\
\hline Total No (\% of responses) & $21 \%$ & $23 \%$ & $23 \%$ & $46 \%$ & $33 \%$ & $38 \%$ & $42 \%$ & $50 \%$ & $67 \%$ & $54 \%$ & $60 \%$ & $63 \%$ & $56 \%$ & $69 \%$ & $69 \%$ & $75 \%$ & $75 \%$ & $85 \%$ & $88 \%$ & $88 \%$ \\
\hline
\end{tabular}

\begin{tabular}{|c|c|c|c|c|c|c|c|c|c|c|c|c|c|c|c|c|c|c|c|c|}
\hline Rating $=1$ ( $\%$ of responses $)$ & $8 \%$ & $13 \%$ & $8 \%$ & $2 \%$ & $23 \%$ & $10 \%$ & $8 \%$ & $15 \%$ & $2 \%$ & $19 \%$ & $12 \%$ & $6 \%$ & $25 \%$ & $6 \%$ & $10 \%$ & $4 \%$ & $6 \%$ & $4 \%$ & $2 \%$ & $4 \%$ \\
\hline Rating $=2$ ( $\%$ of responses $)$ & $17 \%$ & $12 \%$ & $29 \%$ & $15 \%$ & $19 \%$ & $21 \%$ & $17 \%$ & $12 \%$ & $6 \%$ & $10 \%$ & $23 \%$ & $23 \%$ & $10 \%$ & $13 \%$ & $8 \%$ & $6 \%$ & $12 \%$ & $6 \%$ & $6 \%$ & $4 \%$ \\
\hline Rating $=3$ ( $\%$ of responses) & $25 \%$ & $33 \%$ & $25 \%$ & $23 \%$ & $12 \%$ & $25 \%$ & $25 \%$ & $15 \%$ & $12 \%$ & $15 \%$ & $4 \%$ & $6 \%$ & $8 \%$ & $4 \%$ & $8 \%$ & $10 \%$ & $4 \%$ & $6 \%$ & $4 \%$ & $4 \%$ \\
\hline Rating $=4$ ( $\%$ of responses $)$ & $29 \%$ & $17 \%$ & $15 \%$ & $15 \%$ & $13 \%$ & $6 \%$ & $8 \%$ & $8 \%$ & $12 \%$ & $2 \%$ & $2 \%$ & $2 \%$ & $2 \%$ & $8 \%$ & $6 \%$ & $4 \%$ & $4 \%$ & $2 \%$ & $0 \%$ & $0 \%$ \\
\hline
\end{tabular}

\begin{tabular}{|l|c|c|c|c|c|c|c|c|c|c|c|c|c|c|c|c|c|c|c|c|}
\hline Total number of responses & 52 & 51 & 52 & 53 & 52 & 52 & 52 & 52 & 51 & 52 & 52 & 52 & 52 & 52 & 52 & 51 & 52 & 53 & 52 & 52 \\
\hline $\begin{array}{l}\text { Total number of responses no: } \\
\text { responding }\end{array}$ & 1 & 2 & 1 & 0 & 1 & 1 & 1 & 1 & 2 & 1 & 1 & 1 & 1 & 1 & 1 & 2 & 1 & 0 & 1 & 1 \\
\hline
\end{tabular}


Appendix 2: Results for groups vs. individual focus

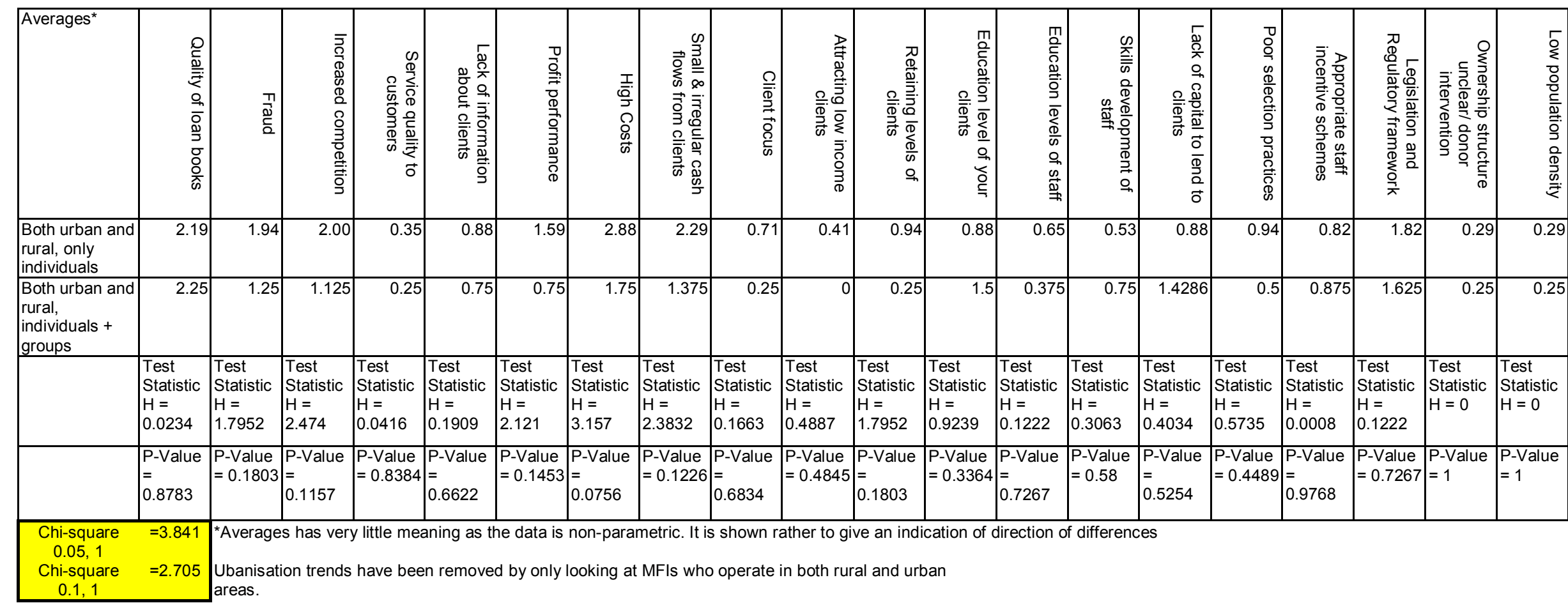


Appendix 3: Urban focus vs. combined rural and urban focus

\begin{tabular}{|c|c|c|c|c|c|c|c|c|c|c|c|c|c|c|c|c|c|c|c|c|}
\hline & 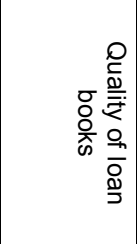 & $\begin{array}{l}\frac{T}{2} \\
\frac{2}{2}\end{array}$ & 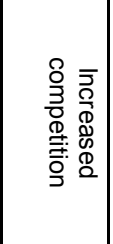 & 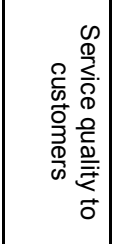 & 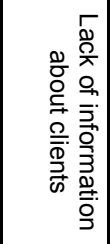 & 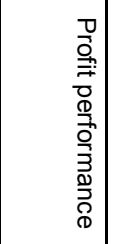 & 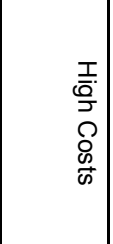 & 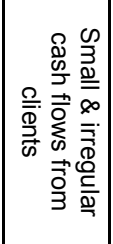 & 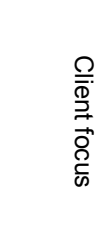 & 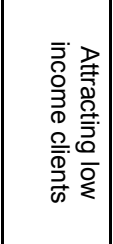 & 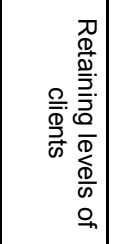 & 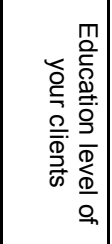 & 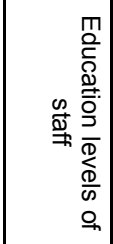 & 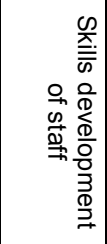 & 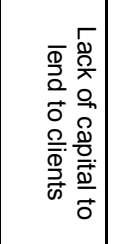 & 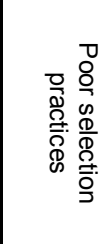 & 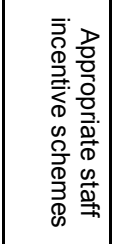 & 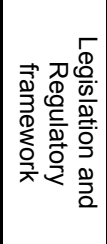 & 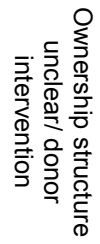 & 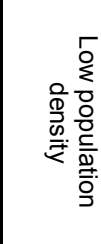 \\
\hline Urban & 1.200 & 0.800 & 1.200 & 0.400 & 1.000 & 0.800 & 1.400 & 0.800 & 0.900 & 0.400 & 0.600 & 1.200 & 0.600 & 0.800 & 0.600 & 0.300 & 0.300 & 1.000 & 0.000 & 0.000 \\
\hline $\begin{array}{l}\text { Urban + Rural } \\
\text { (Both) }\end{array}$ & 2.192 & 2.000 & 2.231 & 0.462 & 1.077 & 1.462 & 2.923 & 2.308 & 0.923 & 0.385 & 0.923 & 0.846 & 0.538 & $\begin{array}{l}0.462 \\
\end{array}$ & 1.083 & 0.769 & 0.692 & 1.846 & 0.000 & 0.154 \\
\hline & $\begin{array}{c}\text { Test } \\
\text { Statistic } \mathrm{H} \\
=2.8997\end{array}$ & \begin{tabular}{|c|} 
Test \\
Statistic \\
$\mathrm{H}=$ \\
3.9385 \\
\end{tabular} & \begin{tabular}{|c|} 
Test \\
Statistic \\
$\mathrm{H}=$ \\
3.0154 \\
\end{tabular} & \begin{tabular}{|c|} 
Test \\
Statistic \\
$\mathrm{H}=$ \\
0.0154 \\
\end{tabular} & \begin{tabular}{|c|} 
Test \\
Statistic \\
$\mathrm{H}=$ \\
0.0779 \\
\end{tabular} & \begin{tabular}{|c|} 
Test \\
Statistic \\
$\mathbf{H}=$ \\
1.3163 \\
\end{tabular} & \begin{tabular}{|c|} 
Test \\
Statistic \\
$\mathrm{H}=$ \\
5.85
\end{tabular} & \begin{tabular}{|c|} 
Test \\
Statistic \\
$\mathrm{H}=$ \\
5.85
\end{tabular} & $\begin{array}{c}\text { Test } \\
\text { Statistic } \\
\mathrm{H}= \\
0.001\end{array}$ & \begin{tabular}{|c|} 
Test \\
Statistic \\
$\mathrm{H}=$ \\
0.024 \\
\end{tabular} & \begin{tabular}{|c|} 
Test \\
Statistic \\
$\mathrm{H}=$ \\
0.1885 \\
\end{tabular} & \begin{tabular}{|c|} 
Test \\
Statistic \\
$\mathrm{H}=$ \\
0.65
\end{tabular} & \begin{tabular}{|c|} 
Test \\
Statistic \\
$\mathrm{H}=$ \\
0.0346
\end{tabular} & $\begin{array}{c}\text { Test } \\
\text { Statistic } \\
H= \\
0.7538\end{array}$ & \begin{tabular}{|c|} 
Test \\
Statistic \\
$\mathrm{H}=$ \\
0.3522 \\
\end{tabular} & $\begin{array}{c}\text { Test } \\
\text { Statistic } \\
\mathrm{H}= \\
0.3846\end{array}$ & \begin{tabular}{|c|} 
Test \\
Statistic \\
$\mathrm{H}=$ \\
1.5385 \\
\end{tabular} & $\begin{array}{c}\text { Test } \\
\text { Statistic } \\
\mathrm{H}= \\
1.5385\end{array}$ & $\mathrm{~N} / \mathrm{A}$ & \begin{tabular}{|c|} 
Test \\
Statistic \\
$\mathrm{H}=$ \\
0.0962
\end{tabular} \\
\hline & $\begin{array}{c}\mathrm{P}-\mathrm{Value}= \\
0.0886\end{array}$ & \begin{tabular}{|c|} 
P-Value \\
$=$ \\
0.0472
\end{tabular} & \begin{tabular}{|c|} 
P-Value \\
$=$ \\
0.0825
\end{tabular} & \begin{tabular}{|c|} 
P-Value \\
$=$ \\
0.9013
\end{tabular} & \begin{tabular}{|c|} 
P-Value \\
$=$ \\
0.7802
\end{tabular} & \begin{tabular}{|c|} 
P-Value \\
$=$ \\
0.2512
\end{tabular} & \begin{tabular}{|c|} 
P-Value \\
$=$ \\
0.0156
\end{tabular} & \begin{tabular}{|c|} 
P-Value \\
$=$ \\
0.0156
\end{tabular} & $\begin{array}{c}\text { P-Value } \\
= \\
0.9753\end{array}$ & \begin{tabular}{|c|} 
P-Value \\
$=$ \\
0.8768
\end{tabular} & \begin{tabular}{|c|} 
P-Value \\
$=$ \\
0.6642
\end{tabular} & \begin{tabular}{|c|} 
P-Value \\
$=$ \\
0.4201
\end{tabular} & \begin{tabular}{|c|} 
P-Value \\
$=$ \\
0.8524
\end{tabular} & \begin{tabular}{|c|} 
P-Value \\
$=$ \\
0.3853
\end{tabular} & \begin{tabular}{|c|} 
P-Value \\
$=$ \\
0.5529
\end{tabular} & $\begin{array}{c}\text { P-Value } \\
= \\
0.5351\end{array}$ & \begin{tabular}{|c|} 
P-Value \\
$=$ \\
0.2148
\end{tabular} & $\begin{array}{c}\text { P-Value } \\
= \\
0.2148\end{array}$ & $\mathrm{~N} / \mathrm{A}$ & $\begin{array}{c}\text { P-Value } \\
= \\
0.7565\end{array}$ \\
\hline $\begin{array}{c}\text { Chi-square } \\
0.05,1\end{array}$ & $=3.841$ & \multicolumn{19}{|c|}{ Removed some noise by only looking at suppliers of consumption credit without insurance who serves individuals only } \\
\hline $\begin{array}{c}\text { Chi-square } \\
0.1,1\end{array}$ & $=2.705$ & \multicolumn{14}{|c|}{ This table shows variance due to differences in urbanisation preferences } & & & & & \\
\hline
\end{tabular}


Appendix 4: Inference of provincial trends

\begin{tabular}{|c|c|c|c|c|c|c|c|c|c|c|c|c|c|c|c|c|c|c|c|c|}
\hline & 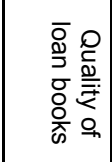 & $\begin{array}{l}\frac{T}{d} \\
\frac{\tilde{d}}{2}\end{array}$ & 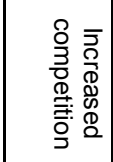 & 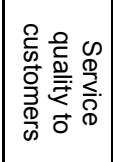 & 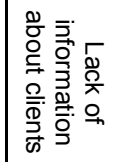 & 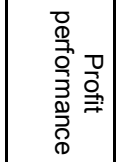 & $\begin{array}{c}\frac{1}{1} \\
\overline{0} \\
0 \\
0 \\
0 \\
\omega \\
0\end{array}$ & 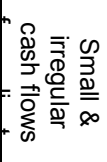 & 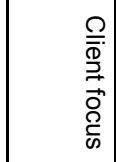 & 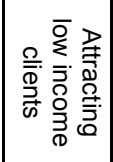 & 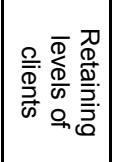 & 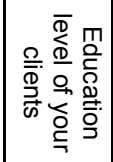 & 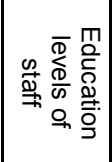 & 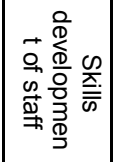 & 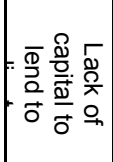 & 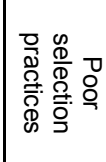 & 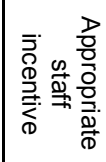 & 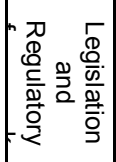 & 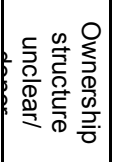 & 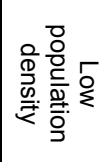 \\
\hline Gauteng ( $\mathrm{n}=7$ ) & 2.714 & 1.714 & 2.000 & 0.714 & 0.571 & 1.143 & 2.429 & 1.857 & 0.571 & 0.429 & 1.143 & 1.714 & 0.429 & 0.857 & 1.167 & 0.857 & 0.857 & 1.714 & 0.286 & 0.286 \\
\hline$N C$ & 1.333 & 1.667 & 1.833 & 0.000 & 0.333 & 1.500 & 2.500 & 1.667 & 0.000 & 0.000 & 0.500 & 1.500 & 0.333 & 0.167 & 1.500 & 0.000 & 0500 & 1.167 & 0.000 & 0.000 \\
\hline \multirow[t]{3}{*}{ E Cape $(n=7)$} & 2.500 & 1.571 & 1.714 & 0.000 & 0.857 & 1.429 & 2.857 & 2.143 & 0.714 & 0.714 & 0.714 & 0.714 & 0.429 & 0.571 & 1.000 & 1.000 & 1.143 & 2.857 & 0.429 & 0.714 \\
\hline & \begin{tabular}{|l|} 
Test \\
Statistic \\
$\mathrm{H}=$ \\
3.4919 \\
\end{tabular} & \begin{tabular}{|l|} 
Test \\
Statistic \\
$\mathrm{H}=$ \\
0.0063
\end{tabular} & \begin{tabular}{|l|} 
Test \\
Statistic \\
$\mathrm{H}=$ \\
0.1578
\end{tabular} & \begin{tabular}{|l|} 
Test \\
Statistic \\
$\mathrm{H}=$ \\
1.0612
\end{tabular} & \begin{tabular}{|l} 
Test \\
Statistic \\
$\mathrm{H}=$ \\
0.3844
\end{tabular} & \begin{tabular}{|l} 
Test \\
Statistic \\
$\mathrm{H}=$ \\
0.3558
\end{tabular} & \begin{tabular}{|l|} 
Test \\
Statistic \\
$\mathrm{H}=$ \\
0.2741
\end{tabular} & \begin{tabular}{|l} 
Test \\
Statistic \\
$\mathrm{H}=$ \\
0.4639
\end{tabular} & \begin{tabular}{|l|} 
Test \\
Statistic \\
$\mathrm{H}=$ \\
2.498
\end{tabular} & \begin{tabular}{|l|} 
Test \\
Statistic \\
$\mathrm{H}=$ \\
0.7163
\end{tabular} & \begin{tabular}{|l|} 
Test \\
Statistic \\
$\mathrm{H}=$ \\
1.0612 \\
\end{tabular} & \begin{tabular}{|l|} 
Test \\
Statistic \\
$\mathrm{H}=$ \\
1.4757
\end{tabular} & \begin{tabular}{|l|} 
Test \\
Statistic \\
$\mathrm{H}=$ \\
0.1272
\end{tabular} & \begin{tabular}{|l|} 
Test \\
Statistic \\
$\mathrm{H}=$ \\
0.9946
\end{tabular} & \begin{tabular}{|l|} 
Test \\
Statistic \\
$\mathrm{H}=$ \\
0.334
\end{tabular} & \begin{tabular}{|l|} 
Test \\
Statistic \\
$\mathrm{H}=$ \\
2.2224
\end{tabular} & \begin{tabular}{|l|} 
Test \\
Statistic \\
$\mathrm{H}=$ \\
0.5837
\end{tabular} & \begin{tabular}{|l|} 
Test \\
Statistic \\
$\mathrm{H}=$ \\
4.2811
\end{tabular} & \begin{tabular}{|l|} 
Test \\
Statistic \\
$\mathrm{H}=$ \\
0.2469
\end{tabular} & \begin{tabular}{|l} 
Test \\
Statistic \\
$\mathrm{H}=$ \\
0.798
\end{tabular} \\
\hline & $\begin{array}{l}\text { P-Value } \\
= \\
0.1745\end{array}$ & $\begin{array}{l}\text { P-Value } \\
= \\
0.9969\end{array}$ & $\begin{array}{l}\text { P-Value } \\
= \\
0.9241\end{array}$ & $\begin{array}{l}\text { P-Value } \\
= \\
0.5882\end{array}$ & $\begin{array}{l}\text { P-Value } \\
= \\
0.8252\end{array}$ & $\begin{array}{l}\text { P-Value } \\
=0.837\end{array}$ & \begin{tabular}{|l|} 
P-Value \\
$=$ \\
0.8719
\end{tabular} & $\begin{array}{l}\text { P-Value } \\
=0.793\end{array}$ & $\begin{array}{l}\text { P-Value } \\
= \\
0.2868\end{array}$ & $\begin{array}{l}\text { P-Value } \\
=0.699\end{array}$ & \begin{tabular}{|l|} 
P-Value \\
$=$ \\
0.5882
\end{tabular} & $\begin{array}{l}\text { P-Value } \\
= \\
0.4781\end{array}$ & \begin{tabular}{|l|} 
P-Value \\
$=$ \\
0.9384
\end{tabular} & $\begin{array}{l}\text { P-Value } \\
= \\
0.6082\end{array}$ & $\begin{array}{l}\text { P-Value } \\
= \\
0.8462\end{array}$ & $\begin{array}{l}\text { P-Value } \\
= \\
0.3292\end{array}$ & $\begin{array}{l}\text { P-Value } \\
= \\
0.7469\end{array}$ & \begin{tabular}{|l} 
P-Value \\
$=$ \\
0.1176
\end{tabular} & \begin{tabular}{|l|} 
P-Value \\
$=$ \\
0.8838
\end{tabular} & $\begin{array}{l}\text { P-Value } \\
=0.671\end{array}$ \\
\hline
\end{tabular}

\begin{tabular}{|c|c|c|c|c|c|}
\hline $\begin{array}{c}\text { Chi-square } 0.05, \\
\mathrm{k}-1=2\end{array}$ & $=5.99$ & Variance due to urbanisation removed by only analysing the both (urban +rural) group & \\
\hline $\begin{array}{c}\text { Chi-square 0.1, } \\
\text { k-1 = 2 }\end{array}$ & $=3.84$ & \\
\hline
\end{tabular}


Appendix 5: Combined product and urbanisation trends

\begin{tabular}{|c|c|c|c|c|c|c|c|c|c|c|c|c|c|c|c|c|c|c|c|c|}
\hline Average & 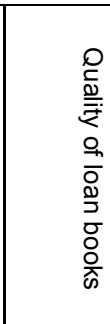 & $\begin{array}{l}\frac{T}{2} \\
\stackrel{2}{2}\end{array}$ & 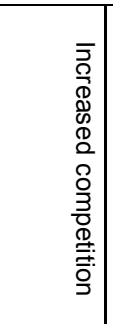 & 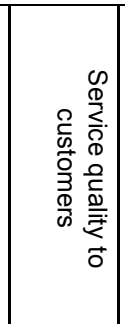 & 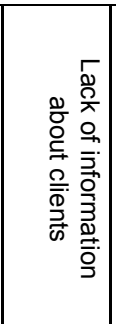 & 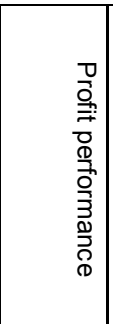 & $\begin{array}{l}\frac{1}{1} \\
\overline{\bar{c}} \\
\overline{0} \\
0 \\
o \\
\omega \\
\omega\end{array}$ & 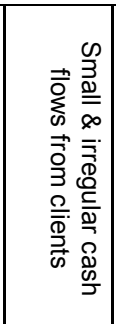 & 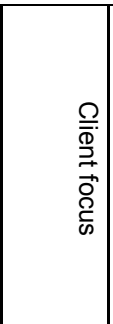 & 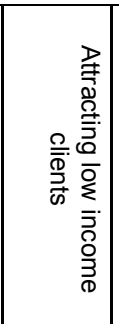 & 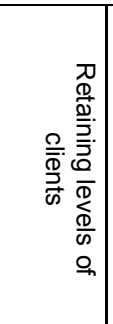 & 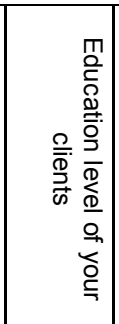 & 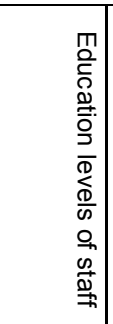 & 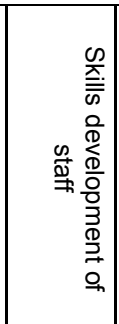 & 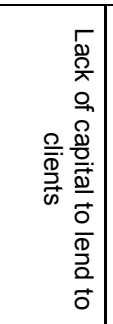 & 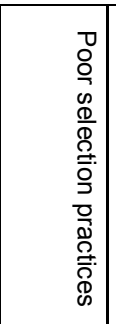 & 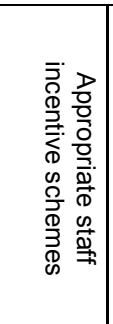 & 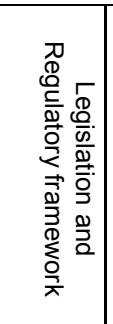 & 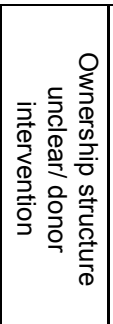 & 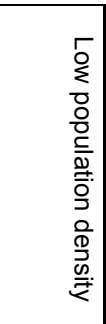 \\
\hline $\begin{array}{l}\text { Only urban clients, } \\
\text { consumption loans } \\
\text { with insurance }\end{array}$ & 2.50 & 1.17 & 1.00 & 0.33 & 0.83 & 1.67 & 2.00 & 2.50 & 0.33 & 1.40 & 1.00 & 1.33 & 0.00 & 0.50 & 1.00 & 0.83 & 1.00 & 1.67 & 0.33 & 0.00 \\
\hline $\begin{array}{l}\text { Only urban clients, } \\
\text { consumption loans } \\
\text { without insurance }\end{array}$ & 1.81 & 1.06 & 1.06 & 0.25 & 0.63 & 1.38 & 1.88 & 1.44 & 1.00 & 0.38 & 0.44 & 1.00 & 0.38 & 0.50 & 0.63 & 0.44 & 0.44 & 1.44 & 0.00 & 0.13 \\
\hline $\begin{array}{l}\text { Urban and rural clients, } \\
\text { consumption loans } \\
\text { with insurance }\end{array}$ & 2.33 & 2.00 & 2.33 & 0.00 & 0.33 & 1.00 & 2.00 & 2.00 & 0.33 & 0.00 & 1.33 & 1.00 & 1.33 & 1.00 & 1.00 & 0.67 & 0.67 & 1.33 & 0.00 & 0.00 \\
\hline \multirow{3}{*}{$\begin{array}{l}\text { Urban and rural clients, } \\
\text { consumption loans } \\
\text { without insurance }\end{array}$} & 2.32 & 1.76 & 2.24 & 0.47 & 1.12 & 1.65 & 2.94 & 2.35 & 0.82 & 0.47 & 1.00 & 1.12 & 0.47 & 0.65 & 1.06 & 0.82 & 0.76 & 1.76 & 0.00 & 0.12 \\
\hline & \begin{tabular}{|c|} 
Test \\
Statistic \\
$\mathrm{H}=$ \\
1.2943 \\
\end{tabular} & \begin{tabular}{|c|} 
Test \\
Statistic \\
$H=$ \\
3.2989 \\
\end{tabular} & \begin{tabular}{c|} 
Test \\
Statistic \\
$H=$ \\
7.6805 \\
\end{tabular} & $\begin{array}{c}\text { Test } \\
\text { Statistic } \\
\mathrm{H}= \\
0.5602 \\
\end{array}$ & \begin{tabular}{|c|} 
Test \\
Statistic \\
$H=$ \\
2.1804 \\
\end{tabular} & \begin{tabular}{|c|} 
Test \\
Statistic \\
$H=$ \\
0.6165 \\
\end{tabular} & \begin{tabular}{|c|} 
Test \\
Statistic \\
$H=$ \\
3.6108 \\
\end{tabular} & \begin{tabular}{|c|} 
Test \\
Statistic \\
$\mathrm{H}=$ \\
4.5614 \\
\end{tabular} & \begin{tabular}{|c|} 
Test \\
Statistic \\
$\mathrm{H}=$ \\
3.7827 \\
\end{tabular} & \begin{tabular}{|c|} 
Test \\
Statistic \\
$H=$ \\
0.2977 \\
\end{tabular} & \begin{tabular}{|c|} 
Test \\
Statistic \\
$H=$ \\
2.2004 \\
\end{tabular} & \begin{tabular}{|c|} 
Test \\
Statistic \\
$H=$ \\
0.6883 \\
\end{tabular} & \begin{tabular}{|c|} 
Test \\
Statistic \\
$H=$ \\
2.8133 \\
\end{tabular} & \begin{tabular}{|c|} 
Test \\
Statistic \\
$H=3.4$
\end{tabular} & \begin{tabular}{c|} 
Test \\
Statistic \\
$H=$ \\
1.7925 \\
\end{tabular} & \begin{tabular}{|c|} 
Test \\
Statistic \\
$\mathrm{H}=$ \\
0.6342 \\
\end{tabular} & \begin{tabular}{|c|} 
Test \\
Statistic \\
$\mathrm{H}=$ \\
1.7164 \\
\end{tabular} & \begin{tabular}{|c|} 
Test \\
Statistic \\
H = \\
0.5294 \\
\end{tabular} & \begin{tabular}{|c|} 
Test \\
Statistic \\
$\mathrm{H}=$ \\
0.4186 \\
\end{tabular} & \begin{tabular}{c|} 
Test \\
Statistic \\
$\mathrm{H}=$ \\
0.2594 \\
\end{tabular} \\
\hline & $\begin{array}{c}\text { P-Value } \\
= \\
0.7305\end{array}$ & \begin{tabular}{|c|} 
P-Value \\
$=$ \\
0.3478
\end{tabular} & $\begin{array}{c}\text { P-Value } \\
= \\
0.0531\end{array}$ & $\begin{array}{c}\text { P-Value } \\
= \\
0.9055\end{array}$ & \begin{tabular}{|c|} 
P-Value \\
$=$ \\
0.5358
\end{tabular} & $\begin{array}{c}\text { P-Value } \\
= \\
0.8927\end{array}$ & $\begin{array}{c}\text { P-Value } \\
= \\
0.3067\end{array}$ & \begin{tabular}{|c|} 
P-Value \\
$=$ \\
0.2069
\end{tabular} & $\begin{array}{c}\text { P-Value } \\
= \\
0.2859\end{array}$ & \begin{tabular}{|c|} 
P-Value \\
$=$ \\
0.9605
\end{tabular} & $\begin{array}{c}\text { P-Value } \\
= \\
0.5319\end{array}$ & \begin{tabular}{|l|} 
P-Value \\
$=0.876$
\end{tabular} & $\begin{array}{c}\text { P-Value } \\
= \\
0.4213\end{array}$ & $\begin{array}{l}\text { P-Value } \\
=0.334\end{array}$ & $\begin{array}{c}\begin{array}{c}\text { P-Value } \\
= \\
0.6166\end{array} \\
0.61\end{array}$ & \begin{tabular}{|c|} 
P-Value \\
$=$ \\
0.8886
\end{tabular} & $\begin{array}{c}\text { P-Value } \\
= \\
0.6333\end{array}$ & $\begin{array}{c}\text { P-Value } \\
= \\
0.9124\end{array}$ & \begin{tabular}{|c|} 
P-Value \\
$=$ \\
0.9364
\end{tabular} & $\begin{array}{c}\text { P-Value } \\
= \\
0.9675\end{array}$ \\
\hline $\begin{array}{c}\text { Chi-square } 0.05 \\
\text { k-1 = } 3\end{array}$ & \multicolumn{20}{|l|}{$=7.814$} \\
\hline $\begin{array}{c}\text { Chi-square 0.1, } \\
\mathrm{k}-1=3\end{array}$ & $=6.25$ & & & & & & & & & & & & & & & & & & & \\
\hline
\end{tabular}


Appendix 6: Statistical data showing difference in income-specific groups

\begin{tabular}{|c|c|c|c|c|c|c|c|c|c|c|c|c|c|c|c|c|c|c|c|c|}
\hline & 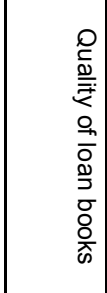 & $\begin{array}{l}T \frac{T}{D} \\
\stackrel{2}{2}\end{array}$ & 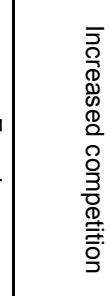 & 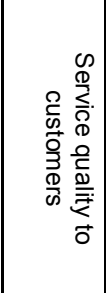 & 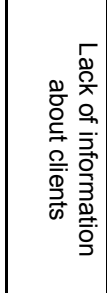 & 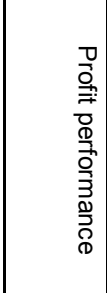 & $\begin{array}{l}I \\
\frac{I}{0} \\
J \\
O \\
0 \\
0 \\
\omega\end{array}$ & 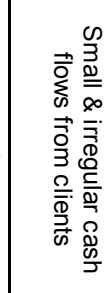 & 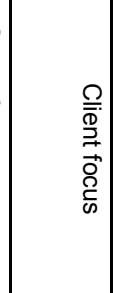 & 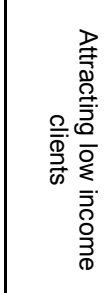 & 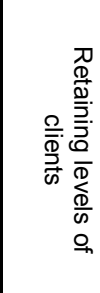 & 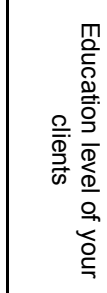 & 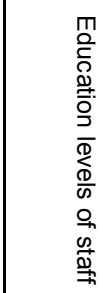 & 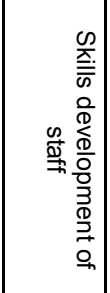 & 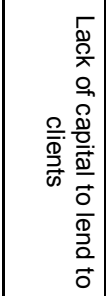 & 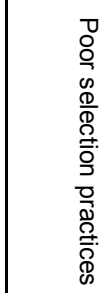 & 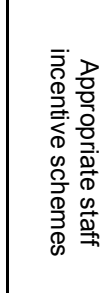 & 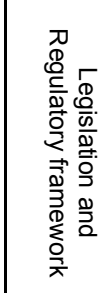 & 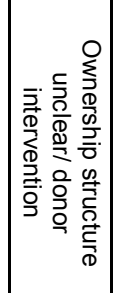 & $\begin{array}{l}5 \\
\vdots \\
0 \\
0 \\
0 \\
0 \\
0 \\
00 \\
0 \\
0 \\
0 \\
0\end{array}$ \\
\hline $\begin{array}{l}\text { Below R800 }(n=18) \\
\text { Urban only }\end{array}$ & 2.286 & 2.143 & 1.571 & 0.429 & 0.714 & 2.714 & 2.714 & 2.286 & 1.000 & 0.714 & 0.857 & 1.286 & 0.429 & \begin{tabular}{|l|}
0.571 \\
\end{tabular} & 0.571 & 0.571 & 0.714 & 2.000 & 0.429 & 0.714 \\
\hline \multirow{3}{*}{$\begin{array}{l}\begin{array}{l}\text { Above R799 }(n=7) \text { Urban } \\
\text { only }\end{array} \\
\text { (a) }\end{array}$} & 1.833 & 1.000 & 1.000 & 0.333 & 1.056 & 1056 & 1.833 & 1.778 & 0.833 & 0.941 & 0.611 & 1.111 & 0.667 & 0.944 & 1.056 & 0.778 & 0.556 & 1.278 & 0.167 & 0.000 \\
\hline & \begin{tabular}{|l|} 
Test \\
Statistic \\
$\mathrm{H}=$ \\
0.4432
\end{tabular} & $\begin{array}{l}\text { Test } \\
\text { Statistic } \\
\mathrm{H}= \\
2.9753\end{array}$ & \begin{tabular}{|l} 
Test \\
Statistic \\
$\mathrm{H}=$ \\
0.9973
\end{tabular} & \begin{tabular}{|l|} 
Test \\
Statistic \\
$\mathrm{H}=$ \\
0.0009
\end{tabular} & \begin{tabular}{|l|} 
Test \\
Statistic \\
$\mathrm{H}=$ \\
0.1108
\end{tabular} & \begin{tabular}{|l|} 
Test \\
Statistic \\
$\mathrm{H}=$ \\
4.88
\end{tabular} & $\begin{array}{l}\text { Test } \\
\text { Statistic } \\
\mathrm{H}= \\
1.2537\end{array}$ & \begin{tabular}{|l} 
Test \\
Statistic \\
$\mathrm{H}=$ \\
0.0082
\end{tabular} & \begin{tabular}{|l|} 
Test \\
Statistic \\
$\mathrm{H}=$ \\
0.0009
\end{tabular} & \begin{tabular}{|l|} 
Test \\
Statistic \\
$\mathrm{H}=$ \\
0.0645
\end{tabular} & \begin{tabular}{|l|} 
Test \\
Statistic \\
$\mathrm{H}=$ \\
0.4432
\end{tabular} & \begin{tabular}{|l|} 
Test \\
Statistic \\
$\mathrm{H}=$ \\
0.619
\end{tabular} & \begin{tabular}{|l} 
Test \\
Statistic \\
$\mathrm{H}=$ \\
0.2344
\end{tabular} & \begin{tabular}{|l|} 
Test \\
Statistic \\
$\mathrm{H}=$ \\
0.619
\end{tabular} & \begin{tabular}{|l|} 
Test \\
Statistic \\
$\mathrm{H}=$ \\
0.619
\end{tabular} & \begin{tabular}{|l} 
Test \\
Statistic \\
$\mathrm{H}=$ \\
0.8242
\end{tabular} & \begin{tabular}{|l|} 
Test \\
Statistic \\
$\mathrm{H}=$ \\
0.7701
\end{tabular} & \begin{tabular}{|l} 
Test \\
Statistic \\
$\mathrm{H}=$ \\
0.88
\end{tabular} & \begin{tabular}{|l|} 
Test \\
Statistic \\
$\mathrm{H}=$ \\
0.033
\end{tabular} & $\begin{array}{l}\text { Test } \\
\text { Statistic } \\
\mathrm{H}= \\
2.6703\end{array}$ \\
\hline & \begin{tabular}{|l|} 
P-Value \\
$=$ \\
0.5056
\end{tabular} & $\begin{array}{l}\text { P-Value } \\
= \\
0.0845\end{array}$ & $\begin{array}{l}\text { P-Value } \\
=0.318\end{array}$ & \begin{tabular}{|l|} 
P-Value \\
$=$ \\
0.9759
\end{tabular} & $\begin{array}{l}\text { P-Value } \\
= \\
0.7392\end{array}$ & $\begin{array}{l}\text { P-Value } \\
= \\
0.0272\end{array}$ & $\begin{array}{l}\text { P-Value } \\
= \\
0.2629\end{array}$ & $\begin{array}{l}\text { P-Value } \\
= \\
0.9277\end{array}$ & \begin{tabular}{|l|} 
P-Value \\
$=$ \\
0.9759
\end{tabular} & $\begin{array}{l}\text { P-Value } \\
= \\
0.7995\end{array}$ & & $\begin{array}{l}\text { P-Value } \\
= \\
0.4314\end{array}$ & $\begin{array}{l}\text { P-Value } \\
= \\
0.6283\end{array}$ & $\begin{array}{l}\text { P-Value } \\
= \\
0.4314\end{array}$ & \begin{tabular}{|l|} 
P-Value \\
$=$ \\
0.4314
\end{tabular} & $\begin{array}{l}\text { P-Value } \\
=0.364\end{array}$ & $\begin{array}{l}\text { P-Value } \\
= \\
0.3802\end{array}$ & $\begin{array}{l}\text { P-Value } \\
= \\
0.3482\end{array}$ & $\begin{array}{l}\text { P-Value } \\
= \\
0.8559\end{array}$ & $\begin{array}{l}\text { P-Value } \\
= \\
0.1022\end{array}$ \\
\hline
\end{tabular}

\begin{tabular}{|c|c|c|c|c|c|c|c|c|c|c|c|c|c|c|c|c|c|c|c|c|}
\hline $\begin{array}{l}\text { Below R800 (n=9) Rural } \\
\text { + Urban }\end{array}$ & 1.000 & 1.222 & 1.667 & 0.000 & 0.111 & 1333 & 2.333 & 1.444 & 0.667 & 0.556 & 0.556 & 1.333 & 0.333 & 0.444 & 1.444 & 0.556 & 0.889 & 2.111 & 0.333 & 0.556 \\
\hline \multirow{3}{*}{$\begin{array}{l}\text { Above R799 }(\mathrm{n}=19) \\
\text { Rural + Urban }\end{array}$} & 2.722 & 1.889 & 1.889 & 0.632 & 1.278 & 1500 & 2.667 & 2.444 & 0.500 & 0.278 & 1.000 & 1.056 & 0.611 & 0.778 & 0.765 & 0.944 & 0.889 & 1.526 & 0.222 & 0.111 \\
\hline & \begin{tabular}{|l|} 
Test \\
Statistic \\
$\mathrm{H}=$ \\
7.26
\end{tabular} & \begin{tabular}{|l|} 
Test \\
Statistic \\
$\mathrm{H}=$ \\
1.8578
\end{tabular} & \begin{tabular}{|l|} 
Test \\
Statistic \\
$\mathrm{H}=$ \\
0.0661 \\
\end{tabular} & \begin{tabular}{|l|} 
Test \\
Statistic \\
$\mathrm{H}=$ \\
1.225 \\
\end{tabular} & \begin{tabular}{|l|} 
Test \\
Statistic \\
$\mathrm{H}=$ \\
6.2229 \\
\end{tabular} & \begin{tabular}{|l|} 
Test \\
Statistic \\
$\mathrm{H}=$ \\
0.1118
\end{tabular} & \begin{tabular}{|l|} 
Test \\
Statistic \\
$\mathrm{H}=$ \\
0.0661
\end{tabular} & \begin{tabular}{|l|} 
Test \\
Statistic \\
$\mathrm{H}=$ \\
3.1488
\end{tabular} & \begin{tabular}{|l|} 
Test \\
Statistic \\
$\mathrm{H}=$ \\
0.0952
\end{tabular} & \begin{tabular}{|l|} 
Test \\
Statistic \\
$\mathrm{H}=$ \\
0.2143
\end{tabular} & \begin{tabular}{|l|} 
Test \\
Statistic \\
$\mathrm{H}=$ \\
1.2229 \\
\end{tabular} & \begin{tabular}{|l|} 
Test \\
Statistic \\
$\mathrm{H}=$ \\
0.5952
\end{tabular} & \begin{tabular}{|l|} 
Test \\
Statistic \\
$\mathrm{H}=$ \\
0.5952
\end{tabular} & \begin{tabular}{|l|} 
Test \\
Statistic \\
$\mathrm{H}=$ \\
0.955
\end{tabular} & \begin{tabular}{|l|} 
Test \\
Statistic \\
$\mathrm{H}=$ \\
0.6536
\end{tabular} & \begin{tabular}{|l|} 
Test \\
Statistic \\
$\mathrm{H}=$ \\
0.5952
\end{tabular} & \begin{tabular}{|l|} 
Test \\
Statistic \\
$\mathrm{H}=$ \\
0.0661
\end{tabular} & \begin{tabular}{|l|} 
Test \\
Statistic \\
$\mathrm{H}=$ \\
0.8282
\end{tabular} & \begin{tabular}{|l|} 
Test \\
Statistic \\
$\mathrm{H}=$ \\
0.0026
\end{tabular} & \begin{tabular}{|l|} 
Test \\
Statistic \\
$\mathrm{H}=$ \\
0.5185
\end{tabular} \\
\hline & $\begin{array}{l}\text { P-Value } \\
= \\
0.0071\end{array}$ & $\begin{array}{l}\text { P-Value } \\
= \\
0.1729\end{array}$ & $\begin{array}{l}\text { P-Value } \\
=0.797\end{array}$ & \begin{tabular}{|l|} 
P-Value \\
$=$ \\
0.2684
\end{tabular} & \begin{tabular}{|l|}
$\begin{array}{l}\text { P-Value } \\
= \\
0.0126\end{array}$ \\
\end{tabular} & $\begin{array}{l}\text { P-Value } \\
= \\
0.7381\end{array}$ & $\begin{array}{l}\text { P-Value } \\
=0.797\end{array}$ & $\begin{array}{l}\text { P-Value } \\
=0.076\end{array}$ & \begin{tabular}{|l|} 
P-Value \\
$=$ \\
0.7576
\end{tabular} & \begin{tabular}{|l}
$\begin{array}{l}\text { P-Value } \\
= \\
0.6434\end{array}$ \\
\end{tabular} & \begin{tabular}{|l|}
$\begin{array}{l}\text { P-Value } \\
= \\
0.2688\end{array}$ \\
\end{tabular} & $\begin{array}{l}\text { P-Value } \\
= \\
0.4404\end{array}$ & $\begin{array}{l}\text { P-Value } \\
= \\
0.4404\end{array}$ & \begin{tabular}{|l|} 
P-Value \\
$=$ \\
0.3284
\end{tabular} & \begin{tabular}{|l} 
P-Value \\
$=$ \\
0.4188
\end{tabular} & \begin{tabular}{|l} 
P-Value \\
$=$ \\
0.4404
\end{tabular} & $\begin{array}{l}\text { P-Value } \\
=0.797\end{array}$ & $\begin{array}{l}\text { P-Value } \\
= \\
0.3628\end{array}$ & \begin{tabular}{|l|} 
P-Value \\
$=0.959$
\end{tabular} & $\begin{array}{l}\text { P-Value } \\
= \\
0.4715\end{array}$ \\
\hline Chi square $0.05,1$ & $=3.841$ & & & & & & & & & & & & & & & & & & & \\
\hline Chi square $0.1,1$ & $\begin{array}{l}=2.705 \\
54\end{array}$ & & & & & & & & & & & & & & & & & & & \\
\hline
\end{tabular}

